\title{
Managing Monterey, Ponderosa, and Sugar Pines to Inhibit Red Turpentine Beetles
}

DAVID L. WOOD, Professor

Emeritus, Department of Environmental Science, Policy, and Management, UC Berkeley;

BRICE A. MCPHERSON, Specialist, Department of Environmental Science, Policy, and Management, UC Berkeley

\section{SUMMARY}

Monterey pines, the most widely planted conifer species in the San Francisco Bay Area, are vulnerable to attack by red turpentine beetles; ponderosa pines and sugar pines are likewise vulnerable. Subsequent infestation by the California fivespined ips can lead to tree mortality. Landowners can protect against attacks by red turpentine beetles by inspecting trees frequently, applying registered pesticides, and pruning only between November 1 and mid-February. Pruning pines and other conifers in warm weather can attract tree-killing bark beetles.

\section{INTRODUCTION}

Monterey pine (Pinus radiata) is the most widely planted conifer species in the San Francisco Bay Area. The species is also widely planted throughout other low-elevation urban areas in California. Native populations of old-growth Monterey pine are found in three areas on the Central Coast of California: Año Nuevo State Park, the Monterey Peninsula, and Cambria. Ponderosa pine (P. ponderosa) is widely distributed throughout forested areas in the western United States and Canada, with a northern range from British Columbia to North Dakota and a southern extent from the coastal mountains in California to the southern Rocky Mountains. Sugar pine (P. lambertiana) appears in forested areas from southern Oregon and northwestern Nevada to Southern California.

More than 170 species of bark beetles are found in California's forests and woodlands (Vega and Hofstetter 2015; Seybold et al. 2008;
Wood et al. 2003; Wood and Storer 2002; Waters et al. 1985; Wood 1982; Furniss and Carolin 1977; Bright and Stark 1973). Bark beetles colonize the cones, branches, limbs, trunks, and roots of trees.

The focus of this article, a literature review, is the role that bark beetles play in the mortality of Monterey pines in California-in particular, in the San Francisco Bay Area. The article provides management recommendations to landowners whose mature Monterey pines might be threatened by bark beetles, but the recommendations also apply to ponderosa and sugar pines.

Bark beetles' biology, and their impacts on host trees, suggest that insecticides should be applied to prevent mortality caused by bark beetles. Two insecticides-Dragnet (permethrin) and Sevin (carbaryl) - are currently registered by the California Department of Pesticide Regulation and the U.S. Environmental Protection Agency (EPA) for protecting conifers from infestation by bark beetles.

Four species of bark beetle are associated with mortality of Monterey pines in California: the red turpentine beetle (Dendroctonus valens), the California fivespined ips (Ips paraconfusus), the Monterey pine ips (I. mexicanus), and the California pine engraver (I. plastographus). Red turpentine beetles, California pine engravers, and Monterey pine ips are found in dead and dying trees in the three native, oldgrowth Monterey pine forests on the Central Coast of California. The California fivespined ips is only rarely found in these native forests. All four species are found in dead and dying Monterey pines that have been planted in California's urban forests (Owen and Adams 2001). 
Rearing studies of infested Monterey pines by Seybold and Wood (unpublished data) demonstrate that the abundance of the three Ips species mentioned above changes as one moves further from the coastal environment in Marin County and toward the inland environment in Contra Costa County (Walnut Creek), a distance of about 25 miles. Whereas the California fivespined ips is most abundant in more inland areas, Monterey pine ips and California pine engravers are most abundant near the California coast and least abundant in inland, low-elevation areas.

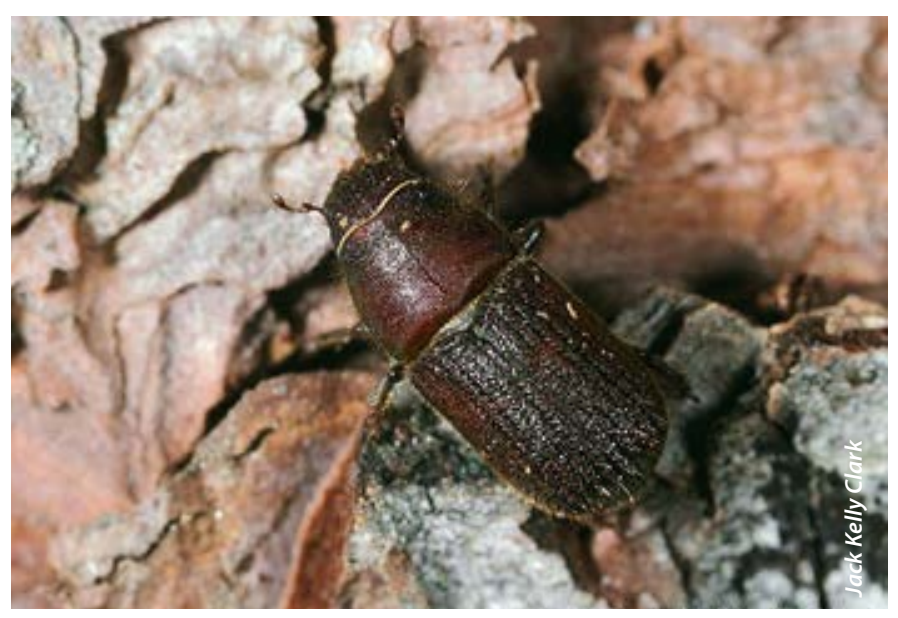

Figure 1. Adult Dendroctonus valens, the red turpentine beetle.

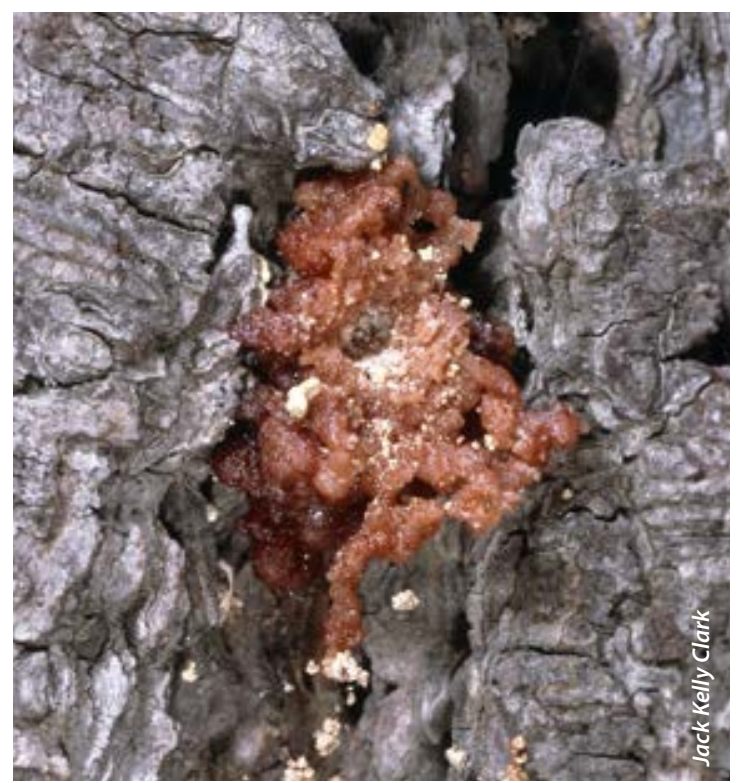

Figure 2. Pitch tubes of Dendroctonus valens on a Monterey pine trunk.

\section{INFESTATION BY BARK BEETLES: SYMPTOMS AND TREATMENT}

\section{Red turpentine beetle}

The red turpentine beetle (fig. 1) attacks primarily the trunk (figs. 2 and 3) and exposed roots (fig. 4) of injured and diseased Monterey pines, but can be found attacking apparently healthy trees as well. These attacks are indicated by streaming resin and "pitch tubes" that appear on the trunk from the root collar to about 5 or 6 feet above the ground. Pitch tubes are globules

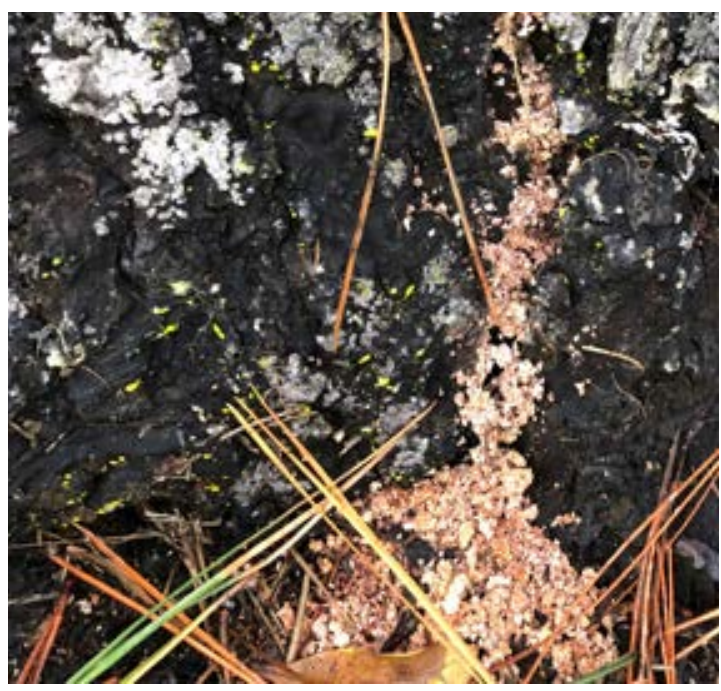

Figure 3. Appearance of Dendroctonus valens frass on a Monterey pine trunk.

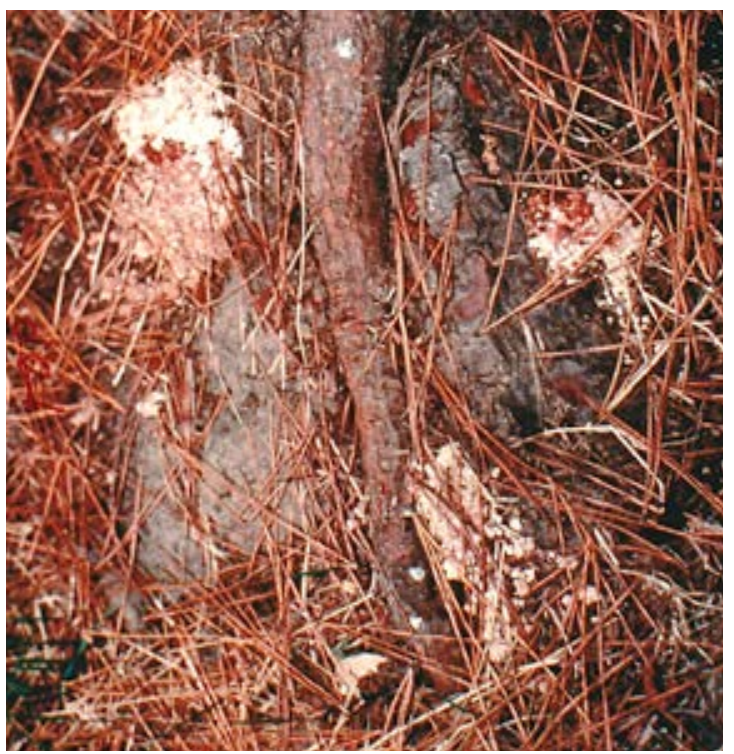

Figure 4. Pitch tubes of Dendroctonus valens on a Monterey pine root. 
Table 1. Comparison of red turpentine beetle and California fivespined ips.

\begin{tabular}{|c|c|c|}
\hline & $\begin{array}{l}\text { Red turpentine beetle } \\
\text { (D. valens) }\end{array}$ & $\begin{array}{l}\text { California fivespined ips } \\
\text { (I. paraconfusus) }\end{array}$ \\
\hline $\begin{array}{l}\text { number of } \\
\text { generations } \\
\text { per year }\end{array}$ & $0.5-2$ & $1-5$ \\
\hline $\begin{array}{l}\text { overwintering } \\
\text { life stage }\end{array}$ & adults and larvae & adults and larvae \\
\hline $\begin{array}{l}\text { adult flight } \\
\text { period }\end{array}$ & Feb. 15-Nov. 1 & Feb. 15-Nov. 1 \\
\hline trees infested & $\begin{array}{l}\text { many pine species, including } \\
\text { Monterey, sugar, ponderosa, } \\
\text { lodgepole, and Jeffrey pines }\end{array}$ & $\begin{array}{l}\text { many pine species, including } \\
\text { Monterey, sugar, ponderosa, } \\
\text { lodgepole, and Jeffrey pines }\end{array}$ \\
\hline $\begin{array}{l}\text { chemical } \\
\text { control }\end{array}$ & $\begin{array}{l}\text { Apply insecticide to prevent } \\
\text { attacks by tree-killing beetles; } \\
\text { use products approved } \\
\text { for control of bark beetles, } \\
\text { following EPA label. Must be } \\
\text { applied by applicator certified } \\
\text { or licensed by the State of } \\
\text { California. Apply to } 2 \text { meters } \\
\text { (7 feet). }\end{array}$ & $\begin{array}{l}\text { If beetles have attacked a tree } \\
\text { but egg galleries are not pres- } \\
\text { ent, the entire bole (trunk) can } \\
\text { be sprayed according to label } \\
\text { instructions. }\end{array}$ \\
\hline
\end{tabular}

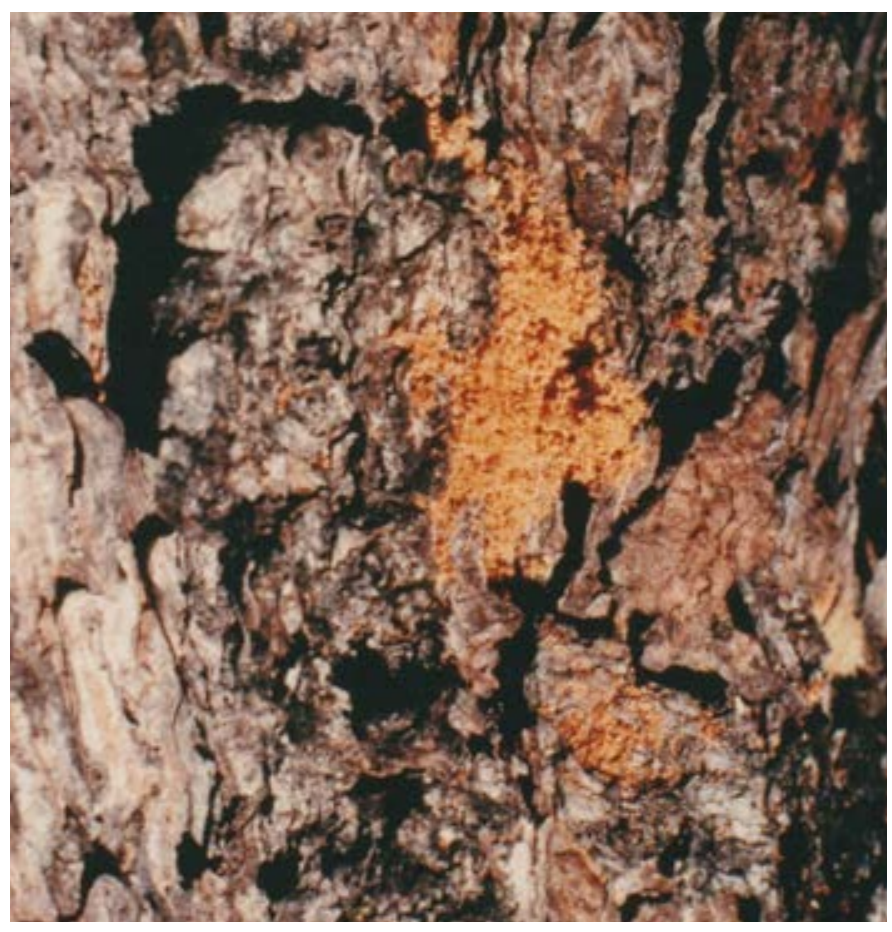

Figure 5. Boring dust marking the entrance tunnel of an Ips paraconfusus beetle on a pine trunk. of resin that flow from the entrance tunnel that the female beetle forms as she penetrates the outer bark to reach the phloem (food-conducting tissue of a tree). Pitch tubes can be milky white-or reddish brown when frass (bark and phloem fragments and fecal material) is extruded from the entrance tunnel (see fig. 2). Frass may appear as chunky fragments spilling from a bark crevice (see fig. 3). On larger trees, attacks can occur for several years without killing the tree. However, repeated attacks by red turpentine beetles can result in the death of Monterey pines if trees are subsequently attacked by the California fivespined ips (Wood et al., unpublished data). In forested areas of the Coast Ranges and the Sierra Nevada, the western pine beetle ( $D$. brevicomis) and the mountain pine beetle (D. ponderosae) infest ponderosa pines previously attacked by the red turpentine beetle (Owen et al. 2005; Wood et al. 2003; Furniss and Carolin 1977).

To decrease the likelihood of Monterey pine mortality, observations of lower tree trunks should be conducted every 1 to 2 weeks, starting in February and continuing until November 1 (Wood, personal observations in a plantation of Monterey pines in Moraga, California, 1965 to present). If pitch streaming or pitch tubes produced by tunneling red turpentine beetles are observed, the lower trunk can be treated with either Dragnet or Sevin to a height of 2 meters (7 feet) (table 1).

\section{California fivespined ips}

In the San Francisco Bay Area, the California fivespined ips-an engraver beetle-has been observed killing Monterey pines that exhibit pitch tubes produced by the red turpentine beetle (Svihra 1995; Wood et al., unpublished observations). Attacks by the California fivespined ips are indicated by small pitch tubes-or more frequently, by reddish-brown frass that is produced by tunneling bark beetles (fig. 5) and accumulates in bark crevices. Frequent inspection for reddish-brown frass resulting from bark beetle attacks, found in bark crevices at the base of trees and in spider webs, is recommended. Once California fivespined ips have initiated galleries, in which 


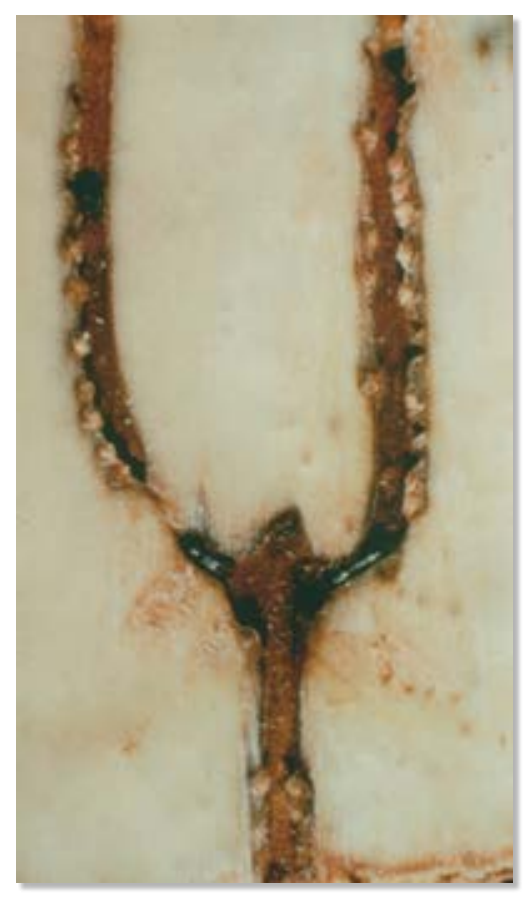

Figure 6. Nuptial chamber and egg in niches in gallery walls of Ips paraconfusus in phloem. eggs are laid, the tree is likely already infested and probably dead, although the foliage may still be green. Therefore, before deciding to apply an insecticide to prevent further attacks, a small portion (1-2 inches) of the outer bark should be removed to determine if galleries are present. Galleries are tunnels $(0.20-0.25$ inches in diameter) that are not packed with frass (fig. 6). If the removed bark does not reveal galleries at breast height, a similar examination should be made at midbole (midtrunk) or in the lower canopy; this is because I. paraconfusus is known to kill the tops of larger Monterey, ponderosa, and sugar pines (Furniss and Carolin 1977).

If inspection and dissection of a small section of bark with reddish boring dust do not reveal the presence of egg galleries, the recommended treatment is to spray the bole with Dragnet or Sevin to the upper canopy. The label permits this bole treatment, but due to the likelihood of insecticide drift to nontarget organisms, this approach should be considered carefully.

Treating a large tree is a major project that requires hydraulic equipment, and insecticide drift is a major concern. See Fettig and Hilszczański (2015) for discussion of the protection from attacks by bark beetles that may be afforded to conifers by the tree injection of insecticides. Infested trees should be removed and either chipped or taken to a composting facility. Contact an arborist, cooperative extension agent, or tree professional for assistance with identifying bark beetle infestations or with insecticide application.

By preventing further attacks by the red turpentine beetle, we hope to reduce stress on trees' defenses and thereby increase resistance to both red turpentine beetles and infestations by ips species. We also hope to interrupt the chemical signaling that likely occurs between these bark beetle species (see below). In urban Monterey pine forests in California, the red turpentine beetle is only rarely associated with mortality of Monterey pines unless the trees have also been attacked by California fivespined ips, a known tree-killing species (personal observation; Wood et al. 2003), or the Monterey pine ips (Owen and Adams 2001).

\section{CHEMICAL SIGNALING BETWEEN BEETLE SPECIES}

What is the evidence for chemical signaling between the red turpentine beetle and a tree-killing bark beetle? Studies at Blodgett Forest Research Station (located in the central Sierra Nevada of California, at 3,400 feet above sea level) showed that over a period of 2.5 years (June 1981 to November 1983), ponderosa pines with pitch tubes produced by red turpentine beetle attacks had a significantly higher rate of mortality caused by western pine beetles and mountain pine beetles than trees without these pitch tubes (Owen et al. 2005). Trees with the highest number of red turpentine beetle pitch tubes exhibited the highest mortality rate. These results suggest that red turpentine beetles produce volatile compounds that attract western pine beetles and mountain pine beetles. However, we could not find scientific evidence that demonstrates the relationship between attacks by the red turpentine beetle and subsequent mortality of Monterey pines caused by California fivespined ips.

Svihra (1995) demonstrated that formulations of permethrin and carbaryl protected Monterey pines from red turpentine beetle infestation for one year. Both the number of trees infested and the number of attacks per tree were greatly reduced by these treatments compared to the controls. However, Svihra did not demonstrate a lower mortality rate caused by red turpentine beetles and California fivespined ips following the insecticide treatments. Nevertheless, it is reasonable to conclude that reducing the attack rate of red turpentine beetles on Monterey pine trees is likely to lead to a reduced mortality rate caused by red turpentine beetles and California fivespined 
ips, either alone or in combination with pitch canker (a disease caused by the fungus Fusarium circinatum).

\section{RELATIONSHIP BETWEEN BEETLE ATTACKS AND PITCH CANKER}

Monterey pine mortality caused by pitch canker was discovered in California in 1986. Later studies (see 2001 review by Gordon et al.) demonstrated that the first infections of pitch canker cause branch tip mortality in the upper canopy, followed by resinous cankers on the trunk. Twig beetles (Pityophthorus spp.) and engraver beetles (Ips spp.) were shown to vector this fungal pathogen into the small branches and trunk, respectively. Ips spp. first killed tops of trees weakened by these infections and then the entire tree. We noted above the association, in native forests, between tree mortality and both Monterey pine ips and the California pine engraver-and, in planted urban forests, between tree mortality and California fivespined ips. In a study of the interactions between bark beetles and pitch canker, Owen and Adams (2001) observed that "No trees died without concurrent colonization by bark beetles." They suggested the use of pesticides to control bark beetles.

\section{TIMING OF TREATMENTS}

Chemicals should be applied just prior to beetles' emergence from overwintering galleries in infested trees-mid-February to mid-March in coastal California forests.

Caution: do not prune conifers after this time period because doing so may release volatile compounds that attract beetles to healthy trees. Hobson et al. (1993) identified monoterpene compounds in oleoresin of ponderosa and sugar pine that were attractive to red turpentine beetles. These attractive compounds were also found in the oleoresin of three co-occurring (sympatric) nonhost conifers: white fir, Douglas-fir, and incense cedar. We do not know if these compounds occur in other conifers planted in urban forests with Monterey pines. However, at least two compounds known to be attractive to red turpentine beetles are found in Monterey pines (Cool and Zavarin 1992). Thus, for all the tree species discussed here, we recommend pruning in winter months: November 1 to mid-February. Because of the warmer climate in Southern California, we suggest treatment with insecticides every 3 months. Pruning pines and other conifers in warm weather can attract tree-killing bark beetles. For other control methods, see Seybold et al. (2008).

\section{CULTURAL MEASURES TO MAINTAIN TREE HEALTH}

The two cultural treatments that have the greatest impact on the health of trees planted in urban environments involve the root system and the canopy of the tree. When the tree's root system is removed in areas adjacent to sidewalks, driveways, and roadways, the tree in effect loses as much as 50 percent of its support. This lost support can result in tree failure at the root collar or in uprooting of uncut roots. When the canopy is thinned, on the other hand, the size of the "sail" is reduced, thus reducing resistance to strong winds. Strong winds can break limbs, the canopy itself, or the main stem-or uproot the tree, causing tree failure. Both these treatments require experience and good judgment from arborists.

Placement of trees at planting time should take into account the probable size of the trees for as long as 50 to 75 years into the future. Tree species is an important variable in anticipating possible tree failure. Periodic inspections by an arborist are important in judging possible dangers from tree failure.

\section{Recommended reading}

For further information on the biology and control of bark beetles in California, we recommend Wood et al. 2003, Waters et al. 1985, Progar et al. 2013, and Fettig and Hilszczański 2015-as well as web resources maintained by the UC Agriculture and Natural Resources Statewide Integrated Pest Management Program, ipm.ucanr.edu/PMG/PESTNOTES/ pn7421.html and http://ipm.ucanr.edu/QT/ barkbeetlescard.html. 


\section{Acknowledgements}

We thank Professor Kenneth Hobson (Department of Biology, University of Oklahoma, retired) for his in-depth review of our manuscript. Dr. Donald Owen (California Department of Forestry and Fire Protection, retired) sent us an important published paper on this subject that we had overlooked. We thank Victor Ghavamzadeh (East Bay Tree Service in Moraga, California) for encouraging us to publish a scientific foundation for recommendations to prune in winter months in Northern California.

\section{REFERENCES}

Bright Jr., D. E., and R. W. Stark. 1973. The bark and ambrosia beetles of California (Coleoptera: Scolytidae and Platypodidae). Bulletin of the California Insect Survey 16. https://essig. berkeley.edu/documents/cis/cis16.pdf

Cool, L. G., and E. Zavarin. 1992. Terpene variability of mainland Pinus radiata. Biochemical Systematics and Ecology 20(2):133-144. https://doi.org/10.1016/03051978(92)90100-R

Fettig, C. J., and J. Hilszczański. 2015. Management strategies for bark beetles in conifer forests. In F. E. Vega and R. W. Hofstetter, eds., Bark beetles: biology and ecology of native and invasive species. New York: Elsevier. https://doi.org/10.1016/B978-012-417156-5.00014-9

Furniss, R. L., and V. M. Carolin. 1977. Western forest insects. U.S. Department of Agriculture, Forest Service, miscellaneous publication 1992. Washington, DC: U.S. Department of Agriculture.

Gordon, T. R., A. J. Storer, and D. L. Wood. 2001. The pitch canker epidemic in California. Plant Disease 85(11):1128-1139. https://doi. org/10.1094/PDIS.2001.85.11.1128

Hobson, K. R., D. L. Wood, L. G. Cool, P. R. White, T. Ohtsuka, I. Kubo, and E. Zavarin. 1993. Chiral specificity in responses by the bark beetle Dendroctonus valens to host kairomones. Journal of Chemical Ecology 19:1837-1846. https://doi.org/10.1007/ BF00983790

Owen, D. R., and D. Adams. 2001. Impact of pitch canker on ornamental Monterey pines in Santa Cruz County, California, U.S., 1987-2000. Journal of Arboriculture 27(6):298-305.

Owen, D. R., D. L. Wood, and J. R. Parmeter. 2005. Association between Dendroctonus valens and black stain root disease on ponderosa pine in the Sierra Nevada of California. The Canadian Entomologist 137(3):367-375. https://doi. org/10.4039/n04-084
Progar, R. A., N. Gillette, C. J. Fettig, and K. Hrinkevich. 2013. Applied chemical ecology of the mountain pine beetle. Forest Science 60(3):414-433. https://doi.org/10.5849/ forsci.13-010.

Seybold, S. J., T. D. Paine, and S. H. Dreistadt. 2008. Bark beetles: integrated pest management for home gardeners and landscape professionals. UC Agriculture and Natural Resources Publication 7421. http:// cecentralsierra.ucanr.edu/files/230149.pdf

Svihra, P. 1995. Prevention of red turpentine beetle attack by Servimol and Dragnet. Journal of Arboriculture 21(4):221-224.

Vega, F. E., and R. W. Hofstetter (eds.). 2015. Bark beetles: biology and ecology of native and introduced species. London: Elsevier.

Waters, W. E., R. W. Stark, and D. L. Wood. 1985. Integrated pest management in pinebark beetle ecosystems. New York: Wiley InterScience.

Wood, D. L., T. W. Koerber, R. F. Scharpf, and A. J. Storer (eds.). 2003. Pests of the native California conifers. Berkeley: University of California Press.

Wood, D. L., and A. J. Storer. 2002. Bark beetles infesting California's conifers. Fremontia 30(3-4):19-25. https://cnps.org/wp-content/ uploads/2018/03/Fremontia_Vol30-No3and4. pdf

Wood, S. L. 1982. The bark and ambrosia beetles of North and Central America (Coleoptera: Scolytidae), a taxonomic monograph. Great Basin Naturalist Memoirs 6. https://www. biodiversitylibrary.org/page/7965093\#page/7/ mode/1u. 
To order or obtain UC ANR publications and other products, visit the UC ANR online catalog at https://anrcatalog.ucanr.edu/ or phone 1-800-994-8849. Direct inquiries to

UC Agriculture and Natural Resources

Publishing

2801 Second Street

Davis, CA 95618

Telephone 1-800-994-8849

E-mail: anrcatalog@ucanr.edu

(2)20 The Regents of the University of California. This work is licensed under the Creative Commons AttributionNonCommercial-NoDerivatives 4.0 International License. To view a copy of this license, visit https://creativecommons.org/ licenses/by-nc-nd/4.0/ or send a letter to Creative Commons, PO Box 1866, Mountain View, CA 94042, USA.

\section{Publication 8682}

ISBN-13: 978-1-62711-137-9

https://doi.org/10.3733/ucanr.8682

The University of California, Division of Agriculture and Natural Resources (UC ANR) prohibits discrimination against or harassment of any person in any of its programs or activities on the basis of race, color, national origin, religion, sex, gender, gender expression, gender identity, pregnancy (which includes pregnancy, childbirth, and medical conditions related to pregnancy or childbirth), physical or mental disability, medical condition (cancer-related or genetic characteristics), genetic information (including family medical history), ancestry, marital status, age, sexual orientation, citizenship, status as a protected veteran or service in the uniformed services (as defined by the Uniformed Services Employment and Reemployment Rights Act of 1994 [USERRA]), as well as state military and naval service.

UC ANR policy prohibits retaliation against any employee or person in any of its programs or activities for bringing a complaint of discrimination or harassment. UC ANR policy also prohibits retaliation against a person who assists someone with a complaint of discrimination or harassment, or participates in any manner in an investigation or resolution of a complaint of discrimination or harassment. Retaliation includes threats, intimidation, reprisals, and/or adverse actions related to any of its programs or activities.

UC ANR is an Equal Opportunity/Affirmative Action Employer. All qualified applicants will receive consideration for employment and/or participation in any of its programs or activities without regard to race, color, religion, sex, national origin, disability, age or protected veteran status.

University policy is intended to be consistent with the provisions of applicable State and Federal laws.

Inquiries regarding the University's equal employment opportunity policies may be directed to: Affirmative Action Compliance and Title IX Officer, University of California, Agriculture and Natural Resources, 2801 Second Street, Davis, CA 95618, (530) 750-1343. Email: titleixdiscrimination@ ucanr.edu. Website: https://ucanr.edu/sites/anrstaff/Diversity/ Affirmative_Action/.
To simplify information, trade names of products have been used. No endorsement of named or illustrated products is intended, nor is criticism implied of similar products that are not mentioned or illustrated.

An electronic copy of this publication can be found at the UC ANR catalog website, http://anrcatalog.ucanr.edu/.

UC. This publication has been anonymously peer PEER reviewed for technical accuracy by University REVIEWED of California scientists and other qualified professionals. This review process was managed by UC ANR Associate Editor for Natural Resources William Stewart.

web-7/20-LC/SO

\section{Warning on the Use of Pesticides}

Pesticides are poisonous. Some pesticides are more toxic than others and present higher risks to people, nontarget organisms, and the environment. A pesticide is any material (natural, organic, or synthetic) used to control, prevent, kill, suppress, or repel pests. "Pesticide" is a broad term that includes insecticides, herbicides (weed or plant killers), fungicides, rodenticides, miticides (mite control,) molluscicides (for snails and slugs), and other materials like growth regulators or antimicrobial products such as bleach and sanitary wipes that kill bacteria.

Always read and carefully follow all precautions and directions provided on the container label. The label is the law and failure to follow label instructions is an illegal use of the pesticide. Store all chemicals in the original labeled containers in a locked cabinet or shed, away from food or feeds, and out of the reach of children, unauthorized persons, and animals. Never place pesticides in food or drink containers. Consult the pesticide label to determine active ingredients, correct locations for use, signal words, and personal protective equipment you should wear to protect yourself from exposure when applying the material.

Pesticides applied in your garden and landscape can move through water or with soil away from where they were applied, resulting in contamination of creeks, lakes, rivers, and the ocean. Confine pesticides to the property being treated and never allow them to get into drains or creeks. Avoid getting pesticide onto neighboring properties (called drift), especially onto gardens containing fruits or vegetables ready to be picked.

Do not place containers with pesticide in the trash or pour pesticides down the sink, toilet, or outside drains. Either use all the pesticide according to the label until the container is empty or take unwanted pesticides to your local Household Hazardous Waste Collection site. Contact your county agricultural commissioner for additional information on safe container disposal and for the location of the Hazardous Waste Collection site nearest you. Follow label directions for disposal of empty containers. Never reuse or burn the containers or dispose of them in such a manner that they may contaminate water supplies or natural waterways. 